\title{
A felnőttnevelési szakemberek formális kiképzési útjai Magyarországon
}

\section{Bevezetés}

Minden szakmának kell, hogy legyenek jól képzett, kompetens képviselői. Az adott szakmára való egyetemi kiképzés a professziók egyik alapfeltételének minősül, amely biztosítja a szakmai tevékenység megfelelő ellátását, tudományos fejlesztését és képviseletét (Despotović, 2010; Evetts, 2011, Egetenmeyer et al., 2019). A felnőttnevelés esetében gyakran nem egyértelmű, hogy ki a szakma ellátója. Ez a bizonytalanság több forrásból származik. Egyrészt nemzetközi színtéren sem beszélhetünk egységes kiképzési rendszerről, amely a felnőttnevelési szakembereket a terület szakszerű ellátására készítené fel. Minden országban más-más megoldások születtek a formális képzési rendszerre, azonban azok elismerése más nemzetállamokban gyakran problémába ütközik (Németh, 2017; Knox \& Fleming, 2010; Zafiris \& Papadimitriou, 2015; Sava \& Lupou, 2009). Másrészt, a felnőttnevelési szakembereknek nincs egységes elnevezésük, amelynek oka lehet a szakemberek körének definiálási nehézsége is. Mindenki foglalkozhat felnőttoktatás szervezésével és lebonyolításával, de ez korántsem elég ahhoz, hogy az oktatás szakszerű és andragógiai-didaktikai módszerek együttesével, jó minőségben és eredményesen valósuljon meg (Reischmann, 2015). Magyarországon többször változott a felnőttnevelési szakemberek kiképzését biztosító egyetemi szakok elnevezése és tartalma, amely negatív hatással van az egységes szakmai identitás, valamint a szakma presztízsének kialakulására és fenntartására. Feltételezhetően ez is az oka annak, hogy az andragógus-identitás egységes jegyei egyelőre nem lelhetők fel a felnőttnevelési szakemberek körében Magyarországon. Feketéné Szakos (2003) kutatása megmutatta, hogy a felnőttnevelési szakemberek tudása, nézetei, a szakmai kifejezések, definíciók használata és a szakmai terminológiák értelmezése jelentősen diverzifikált még a szakemberek körében is. Farkas (2013) pedig arra a következtetésre jutott, a szakemberek birtokolt elméleti ismeretei ugyanolyan lényegesek a minőségi munkavégzésben, mint a gyakorlati tapasztalat.

Magyarországon a felnőttnevelési szakemberek kiképzéséért felelős egyetemi szak öt alkalommal változtatott elnevezést és tartalmi struktúrát az elmúlt évtizedekben. A felnőttnevelési szakemberek voltak már népművelők, közmúvelődési előadók, múvelődésszervezők, andragógusok és közösségszervezők is (Sári, 2016; Maróti, 2014). Nyilván mindegyik elnevezés a szakmában történő tartalmi változásra is utal, amely T. Kiss (2008) szerint a társadalmi elvárásokkal összhangban történt.

$\mathrm{Az}$ andragógia egyetemi képzés történelmi alakulásával számtalan kutató foglalkozott ezidáig, így ezt a témakört ebben a tanulmányban nem fejtem ki részletesen (Juhász, 2009, 2010, 2011, 2016; T. Kiss, 2008, 2009, 2009a; Cserné Aderman, 2006, 2010; Maróit 2008, 2014; Sári, 2016; Farkas, 2015, 2016). $\mathrm{Az}$ eddigi tanulmányok alapján az 1 . ábrán megjelenítem a legfontosabb mérföldköveket a felnőttnevelési szakemberek kiképzésében, de a folytatásban 2006-tól, az andragógia alapszak megalapításától kezdődően vizsgálom ezt a kérdéskört.

\section{1. ábra A felnőttnevelési szakemberek kiképzésének mérföldkövei Magyarországon}

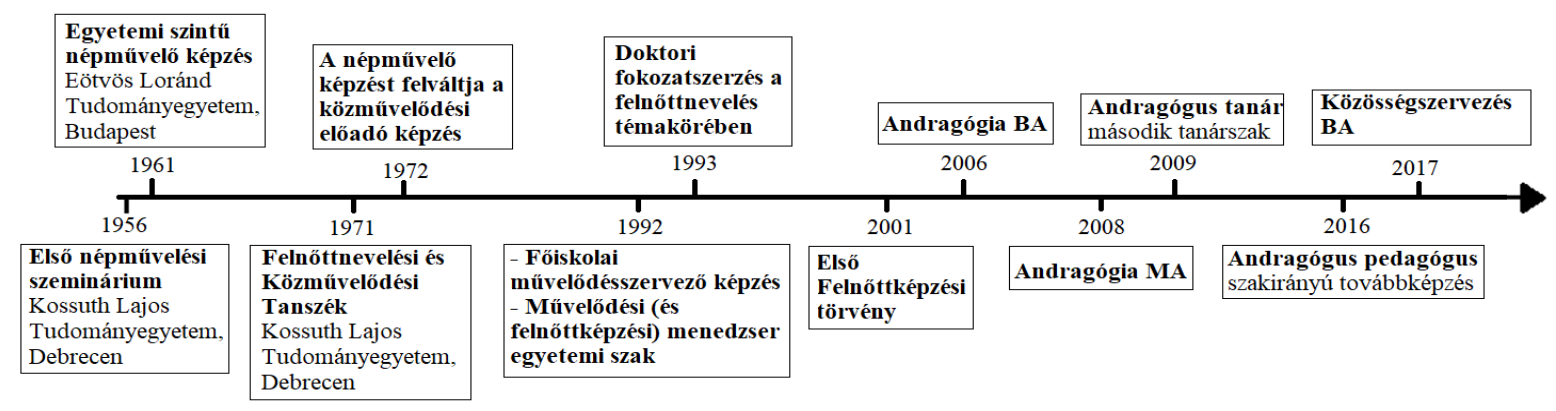

Forrás: T. Kiss (2009) és Juhász (2011) alapján saját szerkesztés 
Az ábrán jól látható, hogy a felnőttnevelési szakemberek kiképzésének számtalan állomása volt 1956tól napjainkig. Mégis, az egyik legfontosabbnak tekinthetők azok az egyetemi alap-, mester- és tanári szakok megjelenése, amelyek az andragógusok célzott egyetemi kiképzését tették lehetővé. Az andagógia alapszak 2006 szeptemberében indult meg legelőször, a Bologna-rendszer keretében. Ezt követte 2008-ban az andragógia mesterszak, 2009-től pedig az andragógus tanár szak vált elérhetővé. A jelentős hallgatói létszámmal múködő andragógia alapszak fejlődésére azonban negatívan hatottak a 2012 utáni kormányzati intézkedések ${ }^{1}$, melyek eredménye a szakra jelentkezők létszámának drasztikus csökkenése volt (Juhász, 2016; Farkas, 2016). Az andragógia alapszak 2015-ben, a felsőoktatásban szerezhető képesítések jegyzékéről és új képesítési jegyzékbe történő felvételéről szóló 139/2015-es számú kormányrendelettel megszűnt. A szak az utolsó évfolyamát 2016 szeptemberében indította el. 2016 után az andragógus tanár szak is átalakuláson ment keresztül, amely szakirányú továbbképzésként jelenleg is andragógus pedagógus néven fut. Az andragógia alapképzés helyét 2016 után a közösségszervezés alapszak vette át, amelynek első évfolyama 2017ben indult. Az andragógia alapszak „utódjaként" megjelenő közösségszervezés szak célja olyan szakemberek kiképzése, akik képesek a különböző kulturális intézmények múködtetésére. Ezen belül olyan feladatok megszervezését és irányítását végzik, amelyek helyi szinten a múvelődés, az ifjúság és a felnőttképzés társadalmi és gazdasági helyzetének fejlesztésére irányulnak (18/2016. EMMI rendelet). A közösségszervezés alapszaknak három szakiránya van, a kulturális közösségszervező, ifjúsági közösségszervező és humánfejlesztő szakirányok. Ez utóbbi örökítette át a felnőttképzéssel kapcsolatos stúdiumokat.

A rövid áttekintés megerősíti, hogy nincs olyan önálló alapképzés ma Magyarországon, amely a felnőttnevelési szakemberek kiképzését célozná. Andragógia mesterképzés jelenleg is múködik, ahol 2020-ban a felvételt nyert hallgatói létszám országosan 48 fő volt (Felvi.hu, 2020). Andragógia alapszak hiányában problémás a mesterszak rekrutációja, annak ellenére, hogy minden bizonnyal a közösségszervező alapszakot befejező hallgatók közül is többen fogják az andragógia mesterszakon folytatni tanulmányaikat.

\section{Kutatási módszerek}

A tanulmányban ismertetett kutatás ${ }^{2}$ a magyarországi felnőttnevelési szakemberképzés egyetemi kiképzési jellemzőinek feltárására, a felsőoktatási intézmények által indított - önálló végzettségi szintet biztosító - közösségszervezés alapszak, andragógia mesterszak és az andragógiai témákat is befogadó neveléstudományi doktori programok tanterveinek ${ }^{3}$ összehasonlító vizsgálatára irányul.

A téma feltárására vonatkozó kutatási kérdések az alábbiak voltak:

a. Milyen képződési utak állnak a felnőttnevelési szakemberek rendelkezésére Magyarországon? Ez hogyan változott az elmúlt évtizedek során?

b. Milyen hasonlóságokat, avagy eltéréseket állapíthatunk meg a magyarországi felsőoktatási intézmények által szervezett közösségszervező alapszak, andragógia mesterszak és neveléstudományi doktori programok tanterveiben?

A tudományos kutatás során a tantervek tartalomelemzését végeztem az Atlas.ti kvalitatív adatelemző program segítségével. Az elemzés során nyílt kódolási technikával, induktív módon kódoltam a tartalmakat/tantárgyakat, tanévek, tartalom és jelleg (kötelező vagy választható) szerint. A tartalomelemzés során a kódokat tantárgycsoportok szerint hoztam létre. A vizsgálat eredményét kvalitatív és kvantitatív szempontból is megvizsgáltam, a nyert adatok skálatípusához mérten (nominális) átlag- és gyakoriságszámításokat, valamin kereszttábla elemzéseket végeztem az SPSS kvantitatív adatelemző programban.

\footnotetext{
${ }^{1}$ Mint például emelt szintű érettségi követelmények bevezetése, államilag támogatott helyek csökkentése, képzésre való bejutás ponthatárának felemelése. Bővebben lásd: Juhász, 2016; Farkas, 2016.

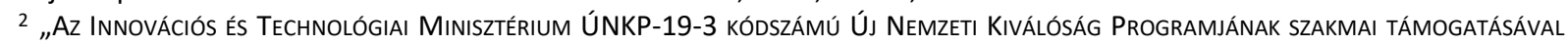
KÉSZÜLT."

${ }^{3}$ A felsőoktatási intézmények és az Országos Doktori Tanács honlapján nyilvánosan elérhető tanterveket alapján
} 


\section{Kutatási eredmények}

Magyarországon több felsőoktatási intézményben folyik közösségszervezés alapképzés, andragógia mesterképzés és neveléstudományi doktori képzés (1. táblázat). Attól függetlenül, hogy a felsőoktatási intézmények rendeletben ${ }^{4}$ szabályozott tanulási eredmény-alapú képzési és kimeneti követelmények alapján dolgozzák ki a képzési programjaikat, azok az intézmény hagyományaival, a helyi igényekkel és a rendelkezésre álló humánerőforrás kapacitással összhangban tartalmukban eltérhetnek. Erre lehetőséget is ad a képzési és kimeneti követelmény, amely az adott szakképzettség kimeneti követelményeit határozza meg, az azok eléréséhez vezető utat nem.

1. táblázat: A felnőttnevelési szakemberek önálló végzettségi szintet biztosító képzési lehetőségei a felsőoktatásban

\begin{tabular}{llll}
\hline & $\begin{array}{l}\text { Közösségszervezés } \\
\text { BA }\end{array}$ & $\begin{array}{l}\text { Andragógia } \\
\text { MA }\end{array}$ & $\begin{array}{l}\text { Neveléstudományi } \\
\text { PhD }\end{array}$ \\
\hline $\begin{array}{l}\text { Képzést indító felsőoktatási } \\
\text { intézmények száma }\end{array}$ & 12 & 6 & 5 \\
\hline
\end{tabular}

\section{A közösségszervezés alapszak hálótervének intézményenkénti összehasonlítása}

A közösségszervezés alapképzés három évig tart, amely során 180 kredit szerezhető. Az előzőekben hangsúlyoztam, hogy a közösségszervezés alapképzés hálóterve felsőoktatási intézményenként eltérhet. Ebből adódóan érdemes röviden áttekinteni a közösségszervezés alapszak hálóterveinek hasonlóságait és eltéréseit. Mivel a közösségszervezés alapszakot összesen 12 felsőoktatási intézmény indítja, azokat az intézményeket vontam be a vizsgálatba, amelyekben 2019 szeptemberében a legmagasabb volt a felvett hallgatók létszáma.

1. ábra: A 2019 szeptemberében induló közösségszervezés alapképzésre felvételt nyert hallgatók létszáma felsőoktatási intézményenként, nappali és levelező tagozaton összesen

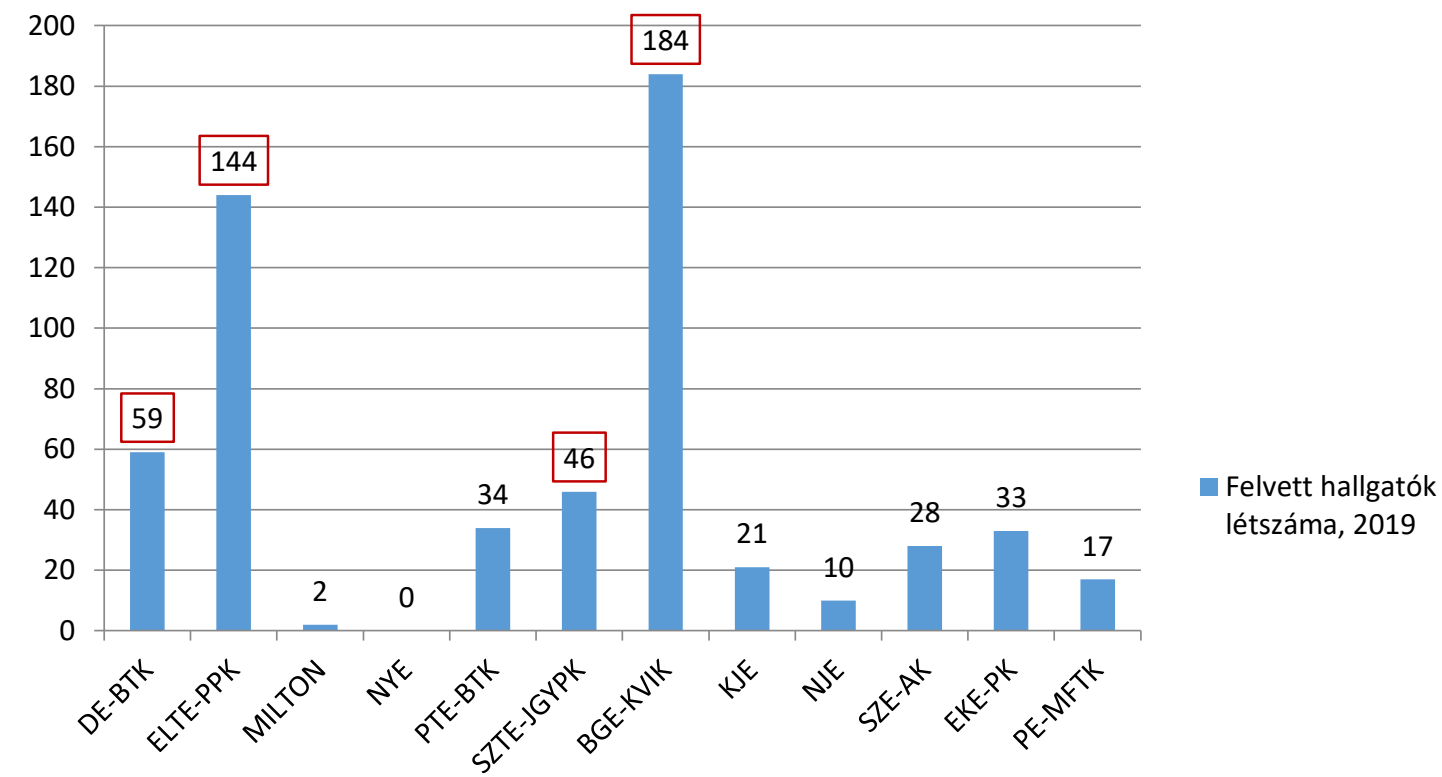

Forrás: felvi.hu (2019) alapján saját szerkesztés

\footnotetext{
4 18/2016. (VIII. 5.) EMMI rendelet a felsőoktatási szakképzések, az alap- és mesterképzések képzési és kimeneti követelményeiről, valamint a tanári felkészítés közös követelményeiről és az egyes tanárszakok képzési és kimeneti követelményeiről szóló 8/2013. (I. 30.) EMMI rendelet módosításáról
} 
A 2. ábra adatai alapján a legtöbb hallgató a Budapesti Gazdasági Egyetem (továbbiakban: BGE), az Eötvös Loránd Tudományegyetem (továbbiakban: ELTE), a Debreceni Egyetem (továbbiakban: DE) és a Szegedi Tudományegyetem (továbbiakban: SZTE) alapképzésére nyert felvételt. A BGE és a DE a három szakirány közül csak kettőt szervez, ezek pedig a kulturális közösségszervezés és a humánfejlesztés szakirányok. Ebből adódóan szem előtt kell tartani, hogy az egyes képzések tantrágyainak számára ez a tény is jelentős hatást gyakorolhat. Az előírt tantárgyak számát évfolyamonként a 2. táblázat szemlélteti.

2. táblázat: A közösségszervezés szak tantárgyainak száma, a kiválasztott intézményekben, évfolyamonként

\begin{tabular}{lllll}
\hline Évfolyam & SZTE & BGE & DE & ELTE \\
\hline 1. évfolyam & 19 & 17 & 20 & 16 \\
2. évfolyam & 32 & 20 & 31 & 23 \\
3. évfolyam & 28 & 17 & 21 & 20 \\
\hline Összesen $^{5}$ & 82 & 55 & 74 & 59 \\
\hline
\end{tabular}

A 2. táblázat adatai alapján látható, hogy jelentős eltérés van az intézmények tantárgyainak számában. A BGE közösségszervezés alapképzésében (2 szakiránnyal) található a legkevesebb tantárgy (55), a legtöbb az SZTE 3 szakiránnyal múködő alapképzésében (82). Itt megjegyzem, hogy például a BGE-n a kötelező tantárgyak mellett $8 \mathrm{db}$ szabadon választható tantárgy is szerepel a tantervben. A tantárgyak száma azt is jelzi, hogy mennyire elaprózott az adott képzési hálóterv. Mivel a teljes képzés összes kreditszáma azonos (180), ezt a kreditszámot pl. az SZTE sokkal több tantárggyal éri el mint a BGE. Tehát pl. az SZTE-n sok és kis kreditszámú tantárgy van, ezzel szemben a BGE-n kevesebb és nagyon kreditszámú tantárgy jelentkezik. A kötelező tantárgyak számát szakiránykonként a 3 . táblázat szemlélteti.

3. táblázat: A közösségszervezés szak tantárgyainak száma, szakirányonként a vizsgált felsőoktatási intézményekben

\begin{tabular}{lllll}
\hline Szakirány & SZTE & BGE & DE & ELTE \\
\hline Kulturális közösségszervezés szakirány & 15 & 8 & 16 & 10 \\
Humánfejlesztés szakirány & 16 & 8 & 16 & 10 \\
Ifjúsági közösségszervezés szakirány & 16 & $/$ & $/$ & 9 \\
\hline Összesen: & 47 & 16 & 32 & 29 \\
\hline
\end{tabular}

Az 3. táblázat adatai alapján az SZTE-n és a DE-n megközelítőleg megegyezik a szakirányonkénti tantárgyak száma (15-16 db). Ezzel szemben a BGE-n és az ELTE-n kevesebb tantárgy szerepel a tantervben (8-10 db). Az egy intézményen belüli tantárgyak száma szakirányonként egyenlő eloszlást mutat.

A tantervek tartalomelemzése (kódolása) során kialakított tantárgycsoportok előfordulása eltérő képet mutat a kiválasztott intézményekben. Eszerint vannak olyan tantárgycsoportok, amelyek minden intézmény tantervében megtalálhatóak, és vannak olyanok, amelyek csak egy-egy intézményben fordulnak elő (4. táblázat). Ilyenek például a szabadon választható és az etika tantárgycsoportok.

\footnotetext{
${ }^{5}$ A tantárgyak össz száma magába foglalja a szakon meghirdetett kötelező tantárgyak és a specializációkhoz tartozó tantárgyak mindegyikét.
} 
4. táblázat: A tantárgycsoportok elöfordulási száma intézményenként

\begin{tabular}{|c|c|c|c|c|}
\hline Tantárgycsoportok & SZTE & BGE & $\mathrm{DE}$ & ELTE \\
\hline andragógia & 14 & 5 & 16 & 11 \\
\hline egyéb & 1 & 6 & 0 & 0 \\
\hline etika & 0 & 1 & 0 & 0 \\
\hline európa-tanulmányok & 1 & 1 & 1 & 2 \\
\hline filozófia & 0 & 1 & 1 & 1 \\
\hline ifjúsági munka & 5 & 0 & 1 & 5 \\
\hline informatika & 1 & 1 & 0 & 0 \\
\hline jog & 2 & 1 & 3 & 3 \\
\hline karriertanácsadás, mentálhigiéné, tréning & 6 & 2 & 2 & 0 \\
\hline közgazdaságtan, vállalkozásismeretek, marketing & 9 & 5 & 12 & 8 \\
\hline közösségfejlesztés & 2 & 4 & 7 & 5 \\
\hline kultúraközvetítés, kulturális intézmények vezetése & 5 & 5 & 5 & 8 \\
\hline kutatásmódszertan & 3 & 1 & 4 & 2 \\
\hline múvelődés és kultúra & 5 & 1 & 5 & 3 \\
\hline múvészetek és esztétika & 2 & 1 & 1 & 0 \\
\hline neveléselméletek & 1 & 1 & 1 & 0 \\
\hline nyelv, kommunikáció, média & 7 & 5 & 4 & 3 \\
\hline pszichológia & 3 & 4 & 1 & 1 \\
\hline szabadon választható & 0 & 8 & 0 & 0 \\
\hline szakmai gyakorla & 5 & 3 & 4 & 4 \\
\hline szociológia & 5 & 2 & 1 & 2 \\
\hline tanuláselméletek & 1 & 2 & 1 & 0 \\
\hline társadalomismeretek & 2 & 2 & 3 & 0 \\
\hline
\end{tabular}

A 4. táblázat jól mutatja, hogy a közösségszervezés alapszak, az andragógia alapszak „utódja”, jelentős mértékben tartalmaz a felnőttnevelés témaköréhez kapcsolódó tantárgyakat. A tantárgycsoportok tartalma specializációként megoszlik, így érdemes figyelembe venni, hogy egy hallgatónak nem mind a 14 feltüntetett tantárgyat kell teljesítenie, hanem annak csak egy részét. A tantárgycsoportok nagyságát tekintve az SZTE-n, a DE-n és az ELTE-n is az andragógia tantárgycsoport a leghangsúlyosabb. A BGE esetében, amennyiben az egyéb, más kategóriába nem sorolható tantárgyakat nem vesszük figyelembe, szintén ez a tantárgycsoport az egyik leghangsúlyosabb a képzésben. Mindegyik vizsgált felsőoktatási intézmény esetében jelentős továbbá a közgazdaságtan tantárgycsoport, emellett pedig a nyelv, kommunikáció és média, a kultúraközvetítés és a szakmai gyakorlat.

A tantárgycsoportok intézményenkénti kapcsolathálóját a 3. ábra mutatja be. Eszerint a legtöbb tantárgycsoport a BGE tantervében ( $23 \mathrm{db}$ ) és az SZTE tantervében jelenik meg ( $21 \mathrm{db}$ ), ezt követi a DE (20 db), valamint az ELTE (15 db). 


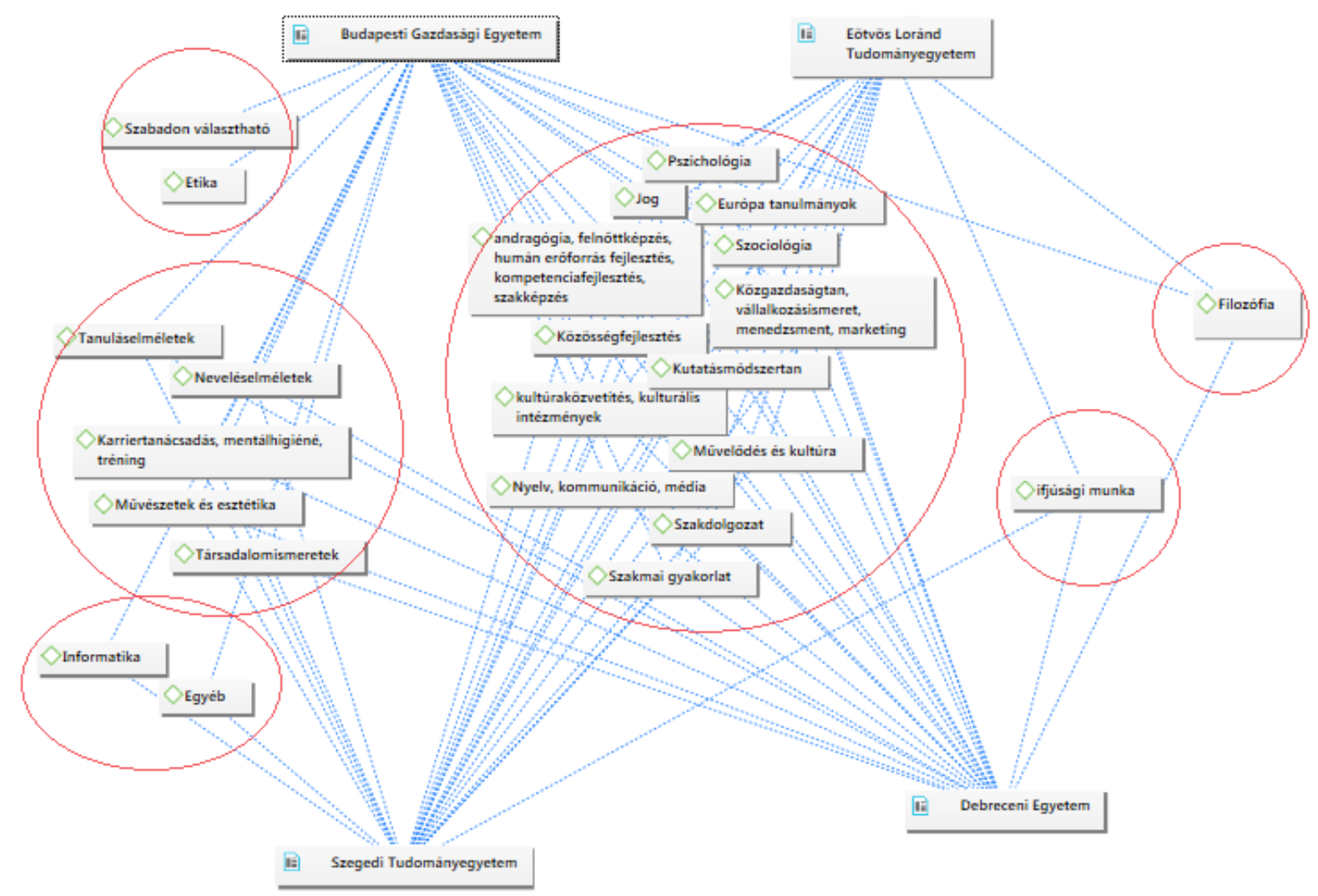

Általános konklúzióként elmondhatjuk, hogy a BGE alapképzése a leginkább szerteágazó, attól függetlenül, hogy ezen intézmény tantervében található meg a legkevesebb tantárgy ( $55 \mathrm{db})$. Ezzel szemben viszont az ELTE közösségszervezés alapképzésében található 59 tantárgy mindössze 15 tantárgycsoportba sorolható, amely a képzés szorosabb vonalvezetését feltételezi.

A tantárgycsoportok intézményenkénti és évfolyamonkénti előfordulását tekintve megállapíthatjuk, hogy minden intézmény alapképzésében az első évben fordul elő a legtöbb tantárgycsoport. A második tanévtől kezdve már kevesebb tantárgycsoport szerepel a tantervekben, amelyek a szakirányoknak megfelelően rajzolódnak ki. A tantárgycsoportok közül az andragógia tantárgycsoport az egyetlen, amely minden tanévben szerepel, mind a négy felsőoktatási intézményben. Ezt követően érdemes áttekinteni az andragógia tantárgycsoporton belüli tantárgyakat is.

$\mathrm{Az}$ andragógia tantárgycsoporton belüli tantárgyak intézményenkénti megjelenését tekintve egyezőség mutatható ki három intézmény tantervében, ezek pedig az ELTE, az SZTE és a DE. Ezen intézményekben a felnőttnevelési tantárgycsoporton belül azonos elnevezésú és tartalmú tantárgyak jelennek meg, amelyek előfordulási száma mutat csak kisebb eltéréseket. Például az Egész életen át tartó tanulás színterei tantárgy az SZTE-n csak egyszer jelentkezik, míg a DE-n két ilyen tantárgyat szerveznek a képzés során. Jelentős különbséget mutat azonban a BGE alapképzésének tanterve, ahol az andragógiához kapcsolódó tantárgyak kevesebb számban jelentkeznek, valamint más megnevezés alatt és összetételben jelennek meg.

Ennek az is (lehet) az oka, hogy az adott szak KKK-jának megfelelően kidolgozott intézményi hálóterv, illetve tantárgystruktúra kialakítását befolyásolja az adott intézményben rendelkezésre álló humán erőforrás is. Az ELTE, az SZTE és a DE tradicionálisan, a kezdetektől fogva folytat közmúvelődési/felnőttképzési képzést (népművelőt, majd művelődésszervezőt, később andragógiát, most közösségszervezőt), tehát ezekben az intézményekben hagyománya van ezeknek a szakoknak és ennek megfelelően a szükséges humánerőforrás is rendelkezésre áll. A BGE fő profilja a 
gazdaságtudományok képzési területhez kapcsolódik, míg a közösségszervezést a bölcsészettudományi képzési területhez sorolhatjuk, így az andragógia témájú tantárgyak megjelenését nyilvánvalóan befolyásol(hat)ja a rendelkezésre álló oktatók képzettsége is.

\section{Az andragógia mesterszak hálótervének intézményenkénti összehasonlítása}

Andragógia mesterszakot hat felsőoktatási intézmény szervez. Ezek a DE, az ELTE, a Nyíregyházi Egyetem (továbbiakban: NYE), a Pécsi Tudományegyetem (továbbiakban: PTE), az SZTE és a Milton Friedman Egyetem (továbbiakban: MILTON). Ebben a fejezetben a felsorolt intézmények négy féléves andragógia mesterképzésének tanterveit hasonlítom össze.

A mesterképzés mintaterveiben szereplő tantárgyak mennyisége intézményenként 29 és 40 között van, a pontos értékeket az 5 . táblázat szemlélteti.

5. táblázat: Az andragógia mesterszak tanterveiben szereplő tantárgyak száma évfolyamonként

\begin{tabular}{lllllll}
\hline Évfolyam & DE & ELTE & MILTON & NYE & PTE & SZTE \\
\hline 1. évfolyam & 14 & 16 & 18 & 17 & 20 & 16 \\
2. évfolyam & 15 & 16 & 14 & 17 & 20 & 14 \\
\hline Összesen: & 29 & 32 & 32 & 34 & 40 & 30
\end{tabular}

A mesterképzések tanterveinek tantárgyi átlaga 33. Kimagasló értéket mutat a PTE, ahol 40 tantárgy szerepel a mintatantervben. Ez ugyanazt a jelenséget mutatja meg, mint amit az alapképzés esetében is megfigyelhetünk. A mesterképzés során 120 kreditet kell teljesíteniük a hallgatóknak. Ha sok tantárgyat tartalmaz egy adott képzés hálóterve, az azt jelenti, hogy a tanterv szétágazó és jellemzően kevesebb kreditértékú tantárgyak jelentkeznek a képzés során.

Két felsőoktatási intézmény mesterképzésében jelennek meg specializációk. Az ELTE-n például két specializációval találkozhatunk, ezek a felnőttképzés-kutatás specializáció és a felnőttképzésmenedzsment specializáció, amelyekhez 4-4 kötelező tantárgy kapcsolódik. Emellett a MILTON-on található a felnőttképzési vezető és a geronto-andragógus specializációk, 5-5 kötelező tantárggyal.

Az ELTE felnőttképzés-menedzsment specializációja hasonló tartalommal bír, mint a MILTON-on található felnőttképzési vezető szakosodás. A specializációkhoz tartozó tantárgyakat az ELTE-n az 4. ábra szemlélteti. Az 5 . ábra pedig bemutatja azokat a tantárgyakat, amelyek a MILTON specializációihoz kapcsolódnak. A felnőttképzési vezető szakosodás a felnőttképzések gyakorlati megvalósulására és a felnőttnevelési intézmények vezetésére készíti fel a hallgatókat, míg a gerontoandragógus specializáció az időskorúak fejlesztésére. Egy későbbi táblázat (6. táblázat) szemlélteti, hogy a szociálandragógia témájú tantárgyak jelentős mértékben megtalálhatók az andragógia mesterszak tanterveiben, amelyek fóként a gerontagógia témakörét érintik, viszont néhány tantárgy a kisebbségek szociálandragógiájával is foglalkozik. 
4. ábra: ELTE, andragógia mesterképzés specializációi

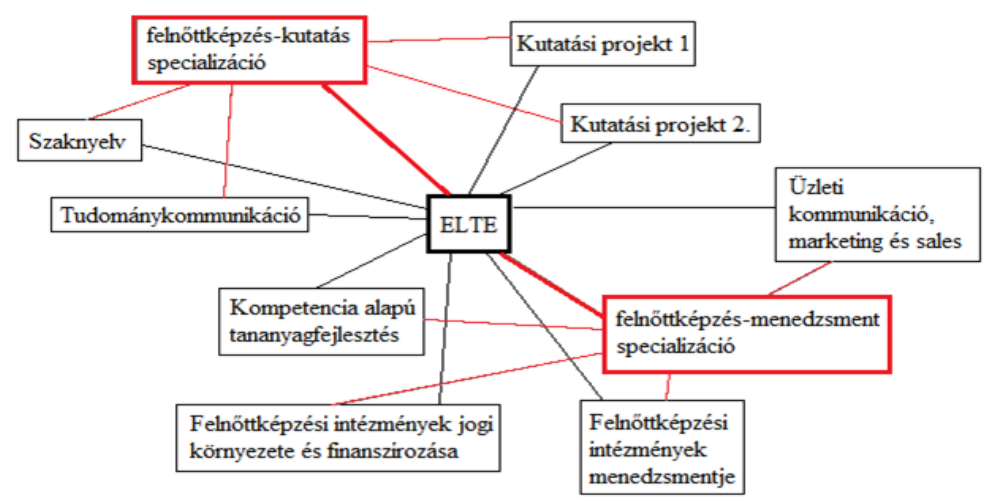

5. ábra: MILTON, andragógia mesterszak specializációi

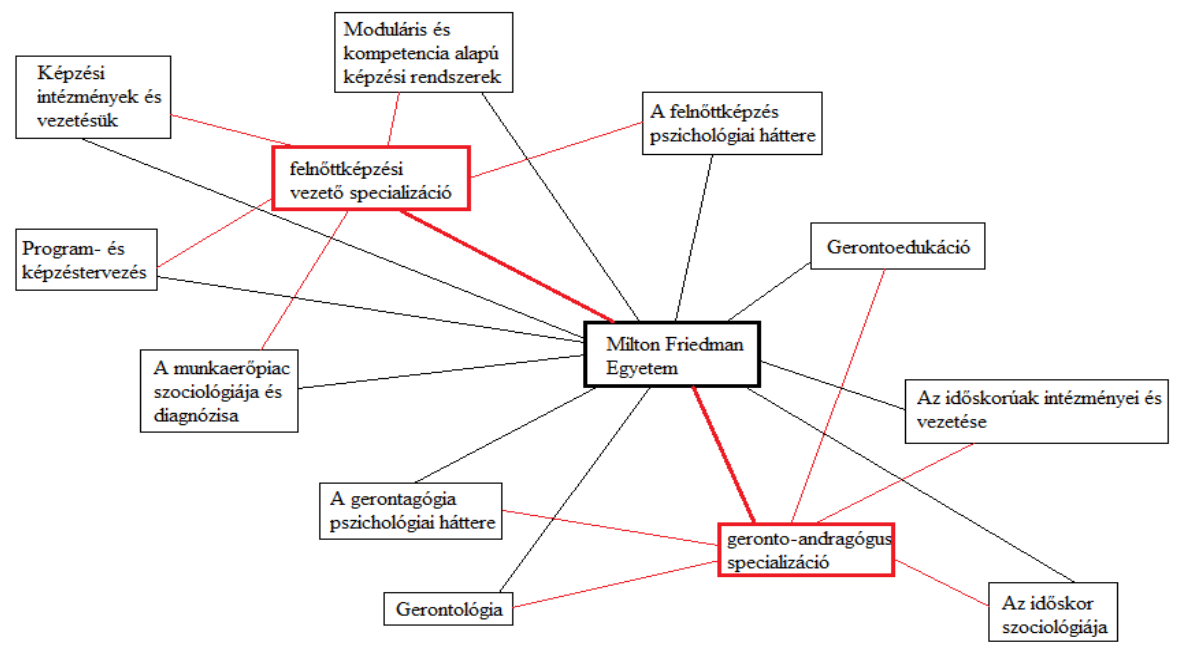

$\mathrm{Az}$ andragógia mesterképzés mintaterveinek elemzése során eltérő kódokat használtam, mint az alapképzés mintatervének elemzésekor. Ennek oka, hogy a közösségszervezés alapszak nem csak a felnőttnevelés tudományterületéből készíti fel a hallgatókat, a szak jellegéhez kapcsolódó szélesebb alapozású kompetenciák fejlesztése a cél. Az andragógia mesterképzés célja pedig a hallgatók elmélyült tudásának és képességeinek biztosítása a felnőttneveléshez fúződő különböző témakörökben, így a tantárgyak csoportosítása eltérő szempontrendszert követelt. Az 6 . táblázat tartalmazza a legdominánsabb tantárgycsoportokat az andragógia mesterképzésekben.

6. táblázat: Tantárgycsoportok elemszáma az andragógia mesterképzésekben

\begin{tabular}{lc}
\hline Tantárgycsoportok & $\mathrm{N}$ \\
\hline Andragógiai kutatások és kutatásmódszertan & 20 \\
$\begin{array}{l}\text { Felnőttnevelés tudományelméleti kérdései } \\
\text { Szociálandragógia }\end{array}$ & 15 \\
$\begin{array}{l}\text { Jogi szabályozás, oktatási rendszerek és politikák } \\
\text { Képzésszervezés és fejlesztés, képzési formák }\end{array}$ & 15 \\
$\begin{array}{l}\text { Csoportvezetés és tanulási/tanítási módszerek } \\
\text { felnőttnevelésben }\end{array}$ & 14 \\
\hline
\end{tabular}


Az 6. táblázat adatai alapján a legtöbb elemszámmal az andragógiai kutatások és kutatásmódszertan tantárgycsoport rendelkezik (20). A legkevesebb (2-2) elemszámmal például az etika, társadalomismeret, pszichológia, IKT tantárgyak jelennek meg.

Az andragógiai „alapozó” tárgyak fontos szerepet játszanak a mesterképzésben, mert az andragógia mesterszakra nem csak andragógia alapszakkal rendelkezők nyerhetnek felvételt. A mesterszakra történő belépéséhez elfogadható szakmai végzettségek például a művelődésszervező, személyügyi szervező, munkavállalási tanácsadó, pedagógia, pszichológia, szociológia, politológia, informatikus könyvtáros, kulturális antropológia, stb.

\section{A neveléstudományi doktori képzések intézményenkénti összehasonlítása}

Azok a hallgatók, akik a mesterképzés befejezését követően doktori képzésben kívánják a tudásukat, valamint tudományos tevékenységüket fejleszteni és folytatni, a Neveléstudományi Doktori Iskolákban tudják megtenni. Ma a DE, az ELTE, a PTE, az Eszterházy Károly Egyetemen (továbbiakban: EKE) és a SZTE-n valósulnak meg neveléstudományi doktori képzések. Ezekben a képzésekben kapnak helyet a felnőttnevelés témakörével foglalkozó kutatások is. A tudományos munkák védésére vonatkozó adatok listáját az Országos Doktori Tanács honlapján ${ }^{6}$ találhatjuk meg, ahol tudományterület, tudományág és időpont szerint végezhetünk keresést az adatbázisban. A tanulmány írásának időpontjában (2020. szeptember) a neveléstudományok területén eddig megvalósult doktori $(P h D)$ értekezések védéseinek száma $N=585$. $A z$ eredményeket Excel táblázatba gyújtöttem, majd az adatbázis kialakítását követően SPSS programban, egyenként kódoltam a tudományos munkákat aszerint, hogy andragógia (felnőttnevelés) vagy pedig pedagógiai témakörökben íródtak. Az 585 találatból összesen $\mathrm{N}=34$ tudományos munkát különítettem el, amelyek témaköre kifejezetten az andragógiához kapcsolódik.

6. ábra: A felnőttnevelés témakörében írt disszertációk száma és intézményi megoszlása, 2006-2020

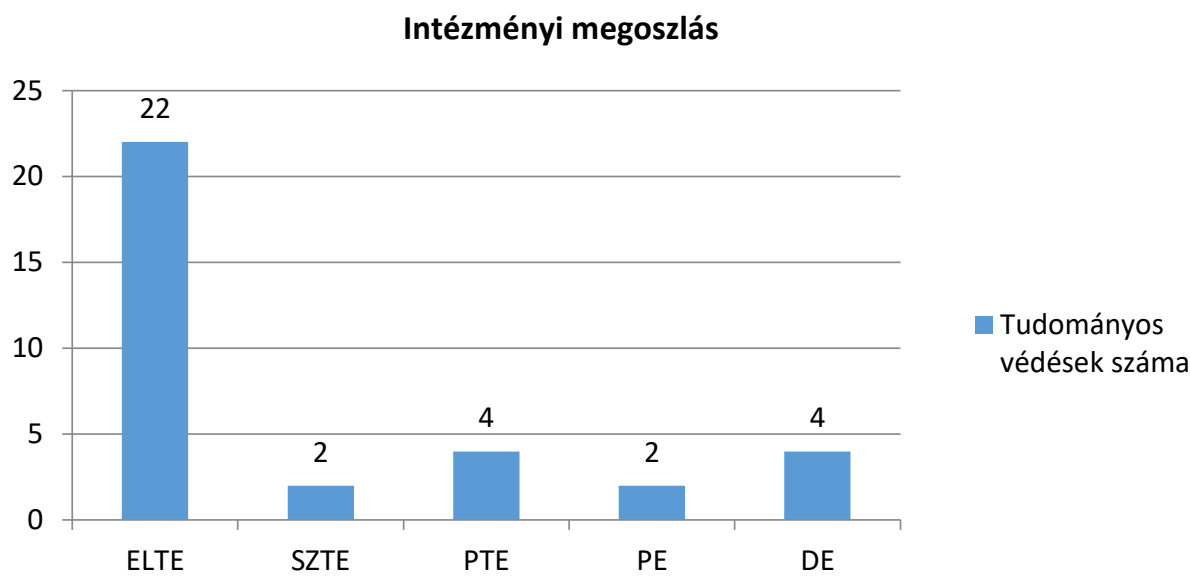

Ahogyan a 6. ábra szemlélteti, 2007 és 2020 között az ELTE került sor a legtöbb felnőttneveléshez kapcsolódó tudományos munka védésére $(\mathrm{N}=22)$. Ezt követi a PTE és a $D E$, összesen 4-4 találattal.

Ha ezt az eredményt összevetjük az összes tudományos védések számával, amelyek a neveléstudományokon belül a pedagógia témaköréhez kapcsolódnak, láthatjuk, hogy az andragógiával (beleértve a szakképzést is) foglalkozó írásművek igencsak alacsony számban jelentkeznek (7. ábra).

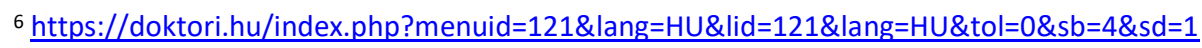


7. ábra: Az andragógiai és egyéb, pedagógiai témájú disszertációk védésének száma, 2006 és 2020 között

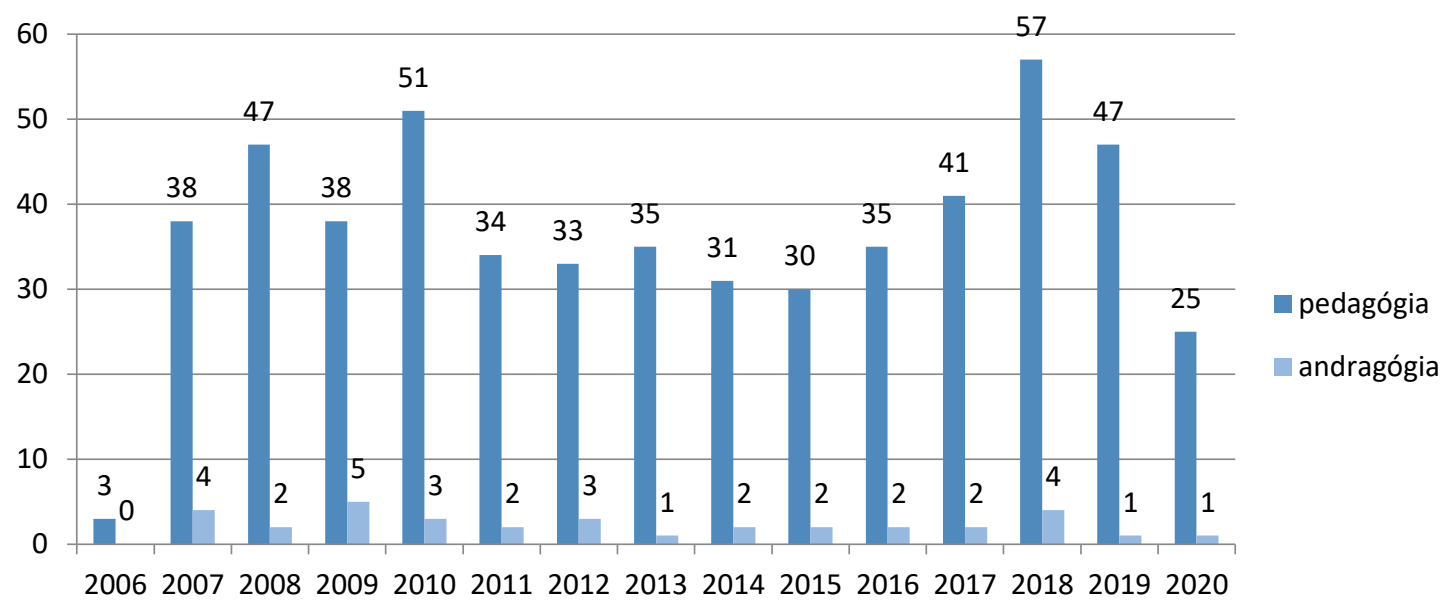

Minden doktori iskola más-más részletességú képzési tantervvel rendelkezik. Az összehasonlítást megnehezítette, hogy a hálótervek nem azonos adatokat tartalmaznak. Emiatt az elemzés során a kötelező tantárgyakra és az andragógia tartalmú tantárgyakra helyeztem a hangsúlyt.

Az elemzés alapján kevés felnőttneveléssel összefüggő tantárgy található a doktori iskolák kínálatában. Emellett mindössze két intézmény keretében, a DE-n és ELTE-n valósul meg felnőttnevelési alprogram/modul. Az első esetében ez a felnőttképzési, szakképzési és közmüvelődési kutatások modul, amely nyilvánvalóan nem csak az andragógia témakörére koncentrál. Tehát kizárólag az ELTE$\mathrm{n}$ van andragógia doktori program. Ami nagyon érdekes eredménynek bizonyul, hogy a DE képzési tanterve ${ }^{7}$ nem tartalmaz felnőttnevelési tantárgyat. Az andragógiai tartalmú tantárgyak számát doktori iskolánként a 8. táblázat szemlélteti.

7. táblázat: Felnőttnevelési tantárgyak száma a neveléstudományi doktori iskolák kínálatában

\begin{tabular}{llllll}
\hline Tantárgycsoport & ELTE & EK & DE & PTE & SZTE \\
\hline Andragógia & 7 & 0 & 0 & 0 & 3 \\
\hline
\end{tabular}

Az SZTE Doktori Iskolájában a felnőttnevelési tantárgyak választható jellegűek. A többi tantárgy részletes elemzése nem volt indokolt, hiszen nem köthetők az andragógia témaköréhez.

\section{Következtetések}

- Jelenleg Magyarországon, alapképzés formájában nem zajlik felnőttnevelési szakemberek kiképzése, azonban az andragógia alapszak „utódja”, a közösségszervezés alapszak (jellemzően a humánfejlesztő szakirány) tartalmaz andragógiai témájú tantárgyakat.

- Eltéréseket fedezhetünk fel a tantárgyak számában és összetételében az alap és mesterképzésben egyaránt. Egyes intézményekre jellemző a tanterv széttagoltsága. Ezekben az esetekben több tantárgy jelentkezik, viszont jellemzően alacsonyabb kreditértékekkel. A tantárgyak számának előfordulása a felsőoktatási intézményeken belül, szakirányok/specializációk és évfolyamok tekintetében is kiegyensúlyozott.

- A közösségszervezés alapképzés esetében jellemzően több andragógia tartalmú tantárgy van azon intézmények hálótervében, amelyek a magyarországi felnőttnevelési szakemberek formális képzésének megjelenése óta foglalkoznak ezen szakemberek kiképzésével. Általános 
megállapítás, hogy a felsőoktatási intézmény rendelkezésére álló szakembergárdája és az intézmény szakmai profilja kihatással van/lehet a képzések tantervének alakulására.

- A neveléstudományi doktori képzésekben alacsony azon doktori értekezések száma, amelyek a felnőttnevelés témájára vonatkoznak. Ez azt is jelenti, hogy az andragógiai kérdések kevésbé vannak a tudományos kutatások fókuszpontjában, mint a pedagógiai témák.

- Magyarországon jelenleg csak az ELTE-n van önálló andragógiai alprogram a doktori iskolák keretében. Emellett csak két felsőoktatási intézményben található andragógiával összefüggő programodul, a DE-n és az ELTE-n. Ettől függetlenül kizárólag az ELTE-n és az SZTE-n találhatunk felnőttneveléssel összefüggő tantárgyakat (az elérhető tantervek alapján). Az Országos Doktori Tanács honlapján elérhető témakiírások áttekintése alapján, 2020-ban, az ELTE-n 13 db (187-ből), az SZTE-n 7 db (241-ből), a PTE-n és a DE-n 4 db (271-ből és 221-ből), az EKE-n pedig 3 db (148-ból) témát találhatunk a felnőttnevelés, szakképzés témakörében. A doktori iskolákban elérhető témák száma egyértelmúen kihatással van az andragógiai kutatások számának alakulására az országban.

\section{Felhasznált irodalom}

- Cserné Aderman, G. (2006). Új szak a képzési palettán: andragógia. Tudásmenedzsment, 7(3), 5-14. http://www.epa.hu/02700/02750/00013/pdf/EPA02750 tudasmenedzsment 2006 01.pdf

- Cserné Aderman, G. (2010). Felnőttoktató, andragógus, andragógus tanár? Felnőttképzési Szemle, 4(1), 59-70. http://epa.oszk.hu/01200/01251/00004/pdf/fef szemle 20101 059070.pdf

- Despotović, M. (2010): Professionalization of Adult Education - between Public and Scientific (non) Recognition. In S. Medić, R. Ebner \& K. Popović (Eds.), Adult Education: The Response to Globa Crisis. Strengths and Chalenges of the Profession (pp. 47-72). Department of Pedagogy and Andragogy, Faculty of Philosophy, University of Belgrade.

- Egetenmeyer, R., Breitschwerdt, L. \& Lechner, R. (2019). From 'traditional professions' to 'new professionalism': A multi-level perspective for analysing professionalization in adult and continuing education. Journal of Adult and Continuing Education, 25(1), 7-24. https://doi.org/10.1177/1477971418814009

- Evetts, J. (2013). Professionalism: Value and ideology. Sociology Review, 61(5-6), 778-796. https://doi.org/10.1177/0011392113479316

- Farkas, É. (2013). A láthatatlan szakma. Tények és tendenciák a felnőttképzés 25 évéröl. typiARt.

- Farkas, É. (2015). A felnőttképzési szakemberek képzésének jelene és jövője? Opus et Educatio, 2(2), 3-12. http://dx.doi.org/10.3311/ope.49

- Farkas, É (2016). Gondolatok a szakemberképzés elmúlt 10 évéről. In E. Sütő, É. Szirmai \& E. Újvári (Eds), Sodrásban. Képzések és kutatások (pp. 33-44). Szegedi Egyetemi Kiadó, Juhász Gyula Felsőoktatási Kiadó. http://acta.bibl.u-szeged.hu/id/eprint/62367

- Felvi.hu (2019). Ponthatárok, jelentkezők és felvettek száma szak(pár)onként. www.felvi.hu

- Felvi. hu (2020). Ponthatárok, jelentkezők és felvettek száma szak(pár)onként. www.felvi.hu

- Feketéné Szakos, É. (2003). Az első hazai andragógiai delfi kutatás eredményeiből. Magyar Pedagógia, 103(3), 339-369. http://www.mpt.bme.hu/wpcontent/uploads/2017/03/Feketene MP1033.pdf

- Juhász, E. (2009). Az andragógus-képzés megújítása a hazai felsőoktatásban. Felnőttképzési szemle, 3(1), 107-113. https://epa.oszk.hu/01200/01251/00003/pdf/fef szemle 200901 107-113.pdf 
- Juhász, E. (2010). Andragógus kompetenciák Bologna elótt és után. In J.T. Karlovitz. (Ed), Felnőttek pályaorientációja, élethosszig tartó tanulása (pp. 77-82), Neveléstudományi Egyesület.

- Juhász, E. (2011). Szakemberképzés a bolognai rendszerben. In E. Gabor (Ed.), Andragógia és közmüvelődés. Régi és új kihívások elött a közmüvelödés az új évtizedben (pp. 39-52). Debreceni Egyetem Neveléstudományok Intézete.

- Juhász, E. (2016). A felnőttek képzése és müvelődése egykor és ma Magyarországon. Csokonai Kiadó.

- Knox, B. A. \& Fleming, E. J. (2010). Professionalization of the Field of Adult and Continuing Education. In E. C. Kasworm, D. A. Rose, M. J. Ross-Gordon (Eds.), Handbook of Adult and Continuing Education (pp. 125-134), SAGE Publication.

- Maróti, A. (2008). A népmúveléstől az andragógiáig. A népmúvelsi szakképzést meghatározó szemlélet átalakulása. In E. Juhász (Ed.), Andragógia és közmüvelődés. A 2006. szeptember 26-27-ei Durkó Mátyás Konferencia és Jubileumi Szakmai Találkozó konferenciakötete (pp. 13-20). http://mek.niif.hu/18700/18788/18788.pdf

- Maróti, A. (2014). Merre tovább andragógia? - A fogalomváltások tanulságai. Opus et Educatio, 1(1). 4-10. http://opuseteducatio.hu/index.php/opusHU/article/view/4/2

- Németh, B. (2017). The Role of Person and Personality in Adult Education. Adult Educators with Changing Missions and Engagements. Andragogical Studies, (2), 9-26. http://doi.org/10.5937/andstud1702009N

- Reischmann, J. (2015). Profesionalizacija obrazovanja odraslih - neki aspekti. Andragoške Studije, (2), 23-37. http://www.as.edu.rs/pdf/articles/388

- Sava, S. \& Lupou, R. (2009). The adult educator in Europe - professionalisation challenges and the alternative of validation of learning outcomes. Procedia Social and Behavioral Sciences, 1(1), 2227-2232. https://doi.org/10.1016/j.sbspro.2009.01.392

- Sári, M. (2016). Régi kihívások, új fordulatok, válaszok a magyar felnőttképzés és múvelődés terén.In E. Juhász (Ed.), A népmüvelőtool a közösségi müvelődésig (pp. 71-83). Debreceni Egyetem TEK BTL, Neveléstudományok Intézete.

- T. Kiss Tamás (2001). A közmúvelődéstől a kulturális menedszerig. Előadás, Közművelődési Nyári Egyetem, 2001. június 26. http://www.fk.jgytf.u-szeged.hu/tanszek/kozmuv/wp/wpcontent/segedanyag/t kiss tamas/segedanyag/A nepnevelotol a kulturalis menedzserig.doc

- T. Kiss, T. (2008): A népmúvelőtől az andragógusig. Tudomány és társadalom, 8(1), 37-44.

- T. Kiss, T. (2009). Paradigm(avákt)ák egy állandóan válto(akoz)ó képzésben (A társadalmi igényekre reagáló szakemberképzés kimunkáltságának kénysuerűségeiről, ellentmondásairól és lehetőségeiről). Felnőttképzési szemle, 3(1), 98-106. https://epa.oszk.hu/01200/01251/00003/pdf/fef szemle 200901 098-106.pdf

- T. Kiss, T. (2009a). Túlélés, alkalmazkodás vagy/és innováció. Kultúra és Közösség, 13(2), 7-20.

- Zarifis, G. K. \& Papadimitriou, A. (2015).What does it take to develop professional adult educators in Europe? Some proposed framework guidelines. Andragoške Studije, (2), 9-22. http://www.as.edu.rs/pdf/articles/387

- 18/2016. (VIII. 5.) EMMI rendelet a felsőoktatási szakképzések, az alap- és mesterképzések képzési és kimeneti követelményeiről, valamint a tanári felkészítés közös követelményeiről és az egyes tanárszakok képzési és kimeneti követelményeiről szóló 8/2013. (I. 30.) EMMI rendelet módosításáról 